\title{
CASP1 wt Allele
}

National Cancer Institute

\section{Source}

National Cancer Institute. CASP1 wt Allele. NCI Thesaurus. Code C49549.

Human CASP1 wild-type allele is located within $11 \mathrm{q} 23$ and is approximately $76 \mathrm{~kb}$ in length. This allele, which encodes caspase-1 protein, is involved in the cleavage of IL-1 beta releasing the active form of this cytokine. Loss of CASP1 gene expression is associated with prostate cancer. 